\title{
Time and the Other: Waiting and Hope among Irregular Migrants
}

\author{
Synnøve Bendixsen and Thomas Hylland Eriksen
}

Once I placed a glass over a bee and imprisoned it... It wandered around in the glass for two days until it understood that there was no way out and then decided that there was nothing to do but sit in a corner motionless and wait and wait, not knowing what it was waiting for.

-Orhan Pamuk, Silent House, 2012: 25

If, by chance or necessity, your wanderings in Oslo took you past St James Church (Jakobskirken) in Hausmannsgata between April 2011 and October 2012, you would inevitably have noticed a clutch of seven or eight green and white, big and small tents, placed next to the church, on a lawn between a bus stop and the river Akerselva. The area encompassed by this improvised camp was cordoned off with broad, white tape, and the entrance was adorned with photos of crying people in what appeared to be a war zone, along with a white sign proclaiming 'WELCOME TO THE PALESTINIAN REFUGEE CAMP!' above a Palestinian flag. A large banner carrying the slogan 'No humans are illegal', black letters on red fabric, faced the street, facilitating legibility for passers-by. If you were to have ventured into the camp, you would have been likely to have been welcomed by a young Palestinian who explained that this was presently his home, and that of twenty-four other men. Visitors were often offered a cup of sweet mint tea, shared, perhaps, with a youth from a pro-Palestinian group, a student, a Norwegian neighbour or a sympathiser who dropped by with money, food, clothes, furniture or news and a bit of encouragement. The party tent used for entertaining visitors was equipped with two threadbare couches and a dinner table brought by activists and Palestinian migrants who worked in pizza or kebab restaurants in the neighbourhood. It had a white plastic roof for protection against rain and 
falling autumn leaves. Some had written their names or their day and place of birth on the white canvas walls, such as 'Came to Norway on 23-6-09, got final rejection from $\mathrm{UDI}^{1} \ldots$ and live on the street ...' or ' 2 years in Norway but live on the street. Next to these messages was an embroidered picture featuring the word 'Palestine'.

The Palestinian tented camp was established by irregular migrants and activists from the alternative house Blitz, an informal grouping associated with punk culture and anarchism. The authorities removed the camp only after eighteen months, and its instigators proclaimed it to be the longest continuous demonstration in Norway, in spite of its ultimate failure. Their objective was to focus on the Norwegian authorities' treatment of Palestinian asylum seekers, and to put pressure on them to re-evaluate their applications and the general legitimacy of Palestinians as political refugees. All applications had been rejected in the first instance.

Ethnographic research on irregular migrants often emphasizes the migrants' limited freedom of action owing to the severity of state control, the inactive time spent waiting, the fear of deportation and the lack of meaning felt by people who find themselves in this liminal situation (de Genova and Peutz 2010; Thomsen et al. 2010). Similarly, during Bendixsen's fieldwork among irregular migrants in Oslo and Bergen, she spoke to many migrants who held the view that everyday life was empty and meaningless, regardless of the everyday activities such as eating and sleeping, because they could neither work, continue their education nor start a family. Their life situation was characterized by uncertainty; they were perennially waiting for a letter from UDI or UNE, ${ }^{2}$ for their lawyer to call or for papers that would strengthen their application for asylum. However, Bendixsen also did fieldwork among migrants who mobilized, protested and actively tried to influence their situation, like the Palestinian migrants in the tented camp. The political mobilization of these migrants may say something about the ways in which non-citizens can be politically active (Bendixsen 2017), but their situation was deeply defined through their condition of waiting. The everyday world of experience among the Palestinians in the tented camp, as for other irregulars, was marked by uncertainty, a temporal limbo and a fear of enforced return. The contrast with the surrounding society - fast-paced, temporally regimented, fuelled by neoliberal production regimes and lubricated by North Sea oil - was striking and signifies not only two kinds of temporality but also implied power discrepancies.

This chapter, which is based on Bendixsen's ethnographic fieldwork on irregular migrants in Norway from 2011 to $2013,{ }^{3}$ problematizes the notion of 
'waiting' as a homogeneous condition or state of being, by showing the ways in which irregular migrants relate to waiting in different ways. La durée, Bergson's (2001 [1889]) concept for the temporality of subjective human experience which he contrasted to mechanical, quantifiable time - ebbs and flows in speed and intensity. It can be cyclical and repetitive, but also linear and cumulative; it can be fast or slow (Eriksen 2001), oriented towards the future or towards the past, as in Schütz's (1967 [1932]) distinction between 'because' and 'in order to' motivations for action, the former justifying a cause of action by referring to the past, the latter pointing to future-oriented projects. Whereas Bergson posits la durée as an ahistorical condition threatened by the quantifying and standardizing discipline of industrialism, Walter Benjamin, in an important critique of Bergson, superimposes a Marxist teleology on the contrasting, or competing, temporal regimes (Benjamin 1968 [1939]), seeing a transcendence of capitalism both as an escape from mechanical time and as a source of new forms of creativity. Seen from this perspective, the empty, flexible time entailed by waiting may have a transformative or even revolutionary potential. Or, in Bergson's (1935) own terms, the durée entailed in waiting constitutes an open time oriented towards the future, as opposed to the closed time in which action is contingent on past expectations and frozen arrangements.

Waiting constitutes a particular kind of temporality. As famously argued by E. P. Thompson (1967), a major rupture from pre-capitalist to industrial capitalist societies concerned the quantification of work routines. In the modern capitalist world, accordingly, waiting is seen unambiguously as wasted time to be avoided if possible since 'time is money' (cf. Schweizer 2008: 3-5). This is also how many of the migrants experience their long wait, where life is 'on hold'. However, waiting can also be transformed into an active kind of time, provided it can be filled with meaningful content. As we will show, some of the migrants pursue strategies enabling them to turn empty waiting into an open-ended activity; as noted by Mountz (2011), life experiences such as sickness, marriage and childbirth may punctuate the otherwise empty waiting time for some migrants.

The bee in the quote from Orhan Pamuk at the beginning of our chapter brings to mind both the power in making someone wait, and the uncertainty of waiting. Notwithstanding Hage's (2009) interdisciplinary volume and a scattering of earlier contributions, like Schwartz's (1975) pioneering work about power, the state and waiting (for services), or Bourdieu's work on time, waiting and power in Kabylia (Bourdieu 1977), the phenomenology of waiting and its social implications remains understudied (but see Brekke 2004; Bayart 2007; Auyero 2012). Considering the life situation of migrants and refugees, it is 
scarcely a coincidence that several recent studies discuss waiting in the context of migration (Brekke 2010; Gray 2011; Mountz 2011; Griffiths et al. 2013).

What is it that we 'do' when we wait for something, given that waiting is normally defined as the opposite of 'doing' something? In what way can waiting be converted into political resistance? Waiting does in fact entail an engagement based on anticipation - an in-order-to motivation - of an improved life. How do conceptualizations of the future influence the ways in which people wait? And what can we say about people's capacity to act in future-oriented ways even in a condition of temporal limbo? Conversely, under which circumstances does the transformation of waiting into directed activity fuelled by hope and anticipation morph back into a passive state?

Taking, as a starting point, the subjective temporalities of the Palestinians in Oslo and their attempts to transcend the empty liminality of their situation, we will explore how they convert empty and meaningless time to an active waiting time' (Gasparini 1995; Brun 2015). We also contrast the slow, circular and directionless time of the refugee camp with the accelerated, neoliberal temporality of the global information age characterizing the Norwegian society in which the camp was located. We thus aim to demonstrate people's capacity to act under conditions of limited autonomy, and to create future-oriented projects under a temporal regime refusing them a defined future.

Talking about the future inevitably prompts questions about the exact temporality of the future (next year? in twenty years? in the next century? after the end of civilization as we know it?). We will take pains to distinguish between different temporal horizons. It should also be noted that hope, anticipation and an often undefined notion and uncertainness of 'the future' does not merely characterize the situation of irregular migrants, or of migrants as such (Griffiths et al. 2013), but is indeed a feature of the human condition. 'The future' is a time when everything falls into place, and it can be any time - or it can be, from a perspective of eschatology, a time of collapse and disaster, which can also in principle occur at any time.

\section{Irregularity and the phenomenology of waiting}

Being an irregular migrant implies that you do not have legal residence in the country, and your status excludes you from rights requiring citizenship or a permit of residence; in the Norwegian case, when the irregular is above 18 years old this would include education, work and access to public health services 
beyond urgent healthcare. It can be assumed that most of the irregular migrants in Norway are former asylum seekers whose application has been rejected, and who have stayed on informally. It is by definition impossible to count irregular migrants, and researchers have estimated the number of irregulars in Norway as somewhere between 18,100 and 56,000 (Mohn et al. 2014). While some continue to live in asylum centres, others live among friends, family or by themselves. Irregularity, moreover, is not a static condition. A person may shift between being a bona fide asylum seeker, an irregular (or illegal) immigrant, an asylum seeker again (if s/he appeals to UNE), and a regular migrant, following a change in legislation or bureaucratic practice. Policy is sufficiently complex, shifting and ambiguous for many migrants to be uncertain about their actual legal status. Recent research on the social and political production of illegality and of 'illegal subjects' (de Genova 2010; Khosravi 2010; Chimienti and Solomos 2011; Bendixsen 2015a) shows the ways in which the categorization as illegal shapes people's lives in fundamental ways, depriving them of rights and resources taken for granted by most and forced to get by through illegal means in the informal sector. Life as an irregular migrant has variously been described as 'wasted' (Bauman 2004) or ephemeral because you can at any time be deported, unceremoniously and routinely, since you are 'outside the law' (Agamben 1998). Maria Amelie, the most famous irregular migrant in Norway owing to her bestselling autobiographical book (Amelie 2010), says that whenever someone knocked on their door in her adolescence, she and her parents immediately feared that it might be the police who had come to deport them. They could not own a credit card or a car, or walk on a red traffic light, owing to the statistically minuscule, but not unthinkable possibility that they might be asked for an ID by a policeman. The lives of irregular migrants are framed by unpredictability, insecurity, uncertainty and indeterminacy (Kjærre 2010; Andersson 2014; Khosravi 2014). They have been deprived of the right to structure their own time or even to participate in the pre-structured temporality of the modern work regime. Their durée therefore comes across as worthless since it is neither chosen nor open-ended.

Waiting can be understood as an empty gap appearing in the interstices between events (Gasparini 1995), but as pointed out by Eriksen (2005), empty time can also be a prerequisite for creativity, since it is only when nothing in particular happens that anything can happen. So waiting cannot merely be defined as empty time devoid of events. It implies a lack of something that may or perhaps will - sooner or later happen. The psychological state of waiting suspends and brackets activities. The natural flow of life will resume only when 
the period of waiting has ended, whether the object of anticipation is your union with the person you love or the arrival of a delayed ferry. Waiting has been described as an 'inactive activity' (Crapanzano 1985), as a 'temporal deviation' (Schweizer 2004: 779) or as being 'out of sync with time' (Brun 2015: 23). The schism between anticipations and events may create an awareness of the passage of time, but also of its lack of direction. To irregular migrants who experience that their lives are on hold until they receive a residence permit, everyday routines may come across as meaningless and are pursued not as living but as mere survival in so far as they take place in a context devoid of direction and content. As Øian (1998) shows in a study of young, unemployed people of both genders, their lack of work also entails a lack of leisure; by default, the unemployed have no holidays or afternoons off work. This is the kind of situation the refugees in the camp were trying to transcend, as we will show later.

Waiting, moreover, entails powerlessness. The ability to make others wait, a familiar way of exerting power by bureaucrats and businesspeople worldwide (Schwartz 1975; some might want to add famous singers, doctors and dentists to the list), turns the subjectivity of waiting into a commitment 'to wait for everything to come from others' (Bourdieu 2000: 237). Waiting thus expresses a domination by others. Through the very act of acquiescent waiting, you show that you have accepted the loss of your control over your own time. Thus, waiting generates vulnerability and humiliation, and its distribution in society is a precise index of power discrepancies. Otherwise very different marginalized groups share the experience of enforced waiting, a tangible expression of their dependence and lack of personal autonomy (Auyero 2012).

When people continue to acquiesce in their waiting, they may express hope, in brief, an orientation towards the future. Yet people's attitudes towards, and experiences of, the waiting process may vary greatly. Gasparini (1995) distinguishes between actors who wait for something indefinite and those who expect something specific to take place at a specific time. The latter are in greater control of their situation than the former, and have a real possibility to influence it; as Gasparini says, 'Control can ... be viewed as forecasting or anticipation - and, therefore, as expectation - which is biased and influenced by the actor in question' (1995: 31). Yet events do not always take place at the expected time, and in the aftermath of one or several thwarted attempts to forecast decisive events, people may - as we will show oscillate between a definite condition of waiting and an indefinite one. Or they may find ways of acting upon their situation, breaking out of the frustrations of open-ended waiting. 
Waiting is a congested crossroads clogging the route leading from the present to the future, but it is also a somewhat itchy, unpleasant chasm between certainty and uncertainty. Lengthy waiting drives you into a rut, or what Hage (2009) calls stuckedness. You become stuck in a liminal phase eating its way backwards and forwards in time, thereby making a mess of both the 'because' and the 'in order to' clauses for justifying courses of action. The arrow of time morphs into a crumpled sheet of paper. Quite unlike a durée that holds out the promise of organic growth or the realization of subjectivity, so often conceptualized by anthropologists as 'the notion that lived experience is grounded in an emergent, flux-like historical process or total relational field' (Hodges 2008: 415), this temporality is stillborn.

We should also say a few words of clarification about the active/passive mode. Although waiting may well be regarded, and is commonly seen, as a 'blockage of action' (Piaget 1981) and as a 'passive activity' producing powerlessness, helplessness and vulnerability (Crapanzano 1985), the political theorist and Beckett connoisseur Paul Corcoran (1989; see also Lakha 2009) views waiting in analogy with 'stalking a prey', as a kind of 'strong and purposeful action' where the waiting person is ready to take action as soon as the opportunity arises. Quite clearly, how to interpret a period of waiting relies not only on its objective circumstances (the likelihood that the object of anticipation will be realized), but also on the ways in which actors relate to the liminal gap time. Just as there are degrees of hope, there are degrees of activity and passivity.

\section{Waiting for nothing}

What are irregular migrants waiting for? The answer varies between contexts and persons. The consequences of waiting vary too. Rundell (2009: 51) asserts that '[w] all wait for futures - yet not for the same ones, nor in the same way, nor at the same tempo' Irregular migrants in Norway wait for an answer to their appeal to UNE, for changes in politics or policy, for documentation strengthening their case, for a call from their lawyer or for something unspecified to happen. What they have in common is a hope for a permanent permit of residence, which can be seen as a condensed symbol of their strivings, hopes and anticipations. Among the Palestinians, this ultimate aim was expressed in various ways. One of the T-shirts they produced and sold to pay for food and electricity, depicted an angry cartoon face wrapped in a Palestinian scarf, bearing the legend 'Give me the damn papers!'. This expression was also used during demonstrations, along 
with slogans such as 'Residence permit for Palestinian refugees' and 'Everybody has the right to a place to live', 'No human being is illegal', and on one of the tents a resident had written 'My dream is to live safely -!'. During conversations with the Palestinian migrants, many recurrently returned to the prospect of acquiring legal documents enabling them to start a family, work or study. Their conceptualizations of the future were mainly tied to the pivotal point in time when they acquired their permit of residence. This projected event was their main point of reference for the future and a main motivation for continued waiting, which indicates the limitations of the opportunity space in which they found themselves. To them, the period of waiting would end only then, although many feared enforced return as a less desirable, but perhaps equally likely, end of the waiting period.

The political mobilization instigated by the irregular Palestinians must be understood on the basis of both their irregularity and their statelessness, as often pointed out by the residents of the camp. In their view, this made them a special category of asylum seekers. Until 2008, many Palestinians from Gaza and the West Bank were granted asylum in Norway. A policy change in 2008 limited their rights to asylum. More recently arrived Palestinians thus found themselves at a dead end, having had their applications rejected, but they continued to stay in Norway in the hope that things might change.

In February 2011, Palestinian asylum seekers and irregular migrants organized a demonstration in front of the parliament in Oslo, pleading with the Norwegian authorities to re-evaluate their claims to asylum. Participants, who had learned about the initiative largely through a Facebook group for Palestinians in Norway, came from around the country. Hamza, one of the initiators of the demonstration and subsequent developments, explains that during this demonstration, they were approached by young activists from Blitz, offering for them to sleep in the Blitz house, a ramshackle city block that had itself been occupied illegally or semi-legally by punk rockers and anti-authoritarian activists since the early 1980s. What was initially planned as a one-off demonstration grew into a longterm mobilization, with activists from Blitz offering knowledge and skills about how to stage demonstrations in Norway (e.g. obtaining a permit from the police) and help to shape the content of speeches. After nearly two months of demonstrations in central Oslo during early spring 2011, the mobilization grew, and now included slogans such as 'Palestinians seek asylum from the Israeli war machine' and 'We want a chance. Eventually, two large party tents were raised on Eidsvoll Plass, an oblong square connecting the parliament with the National Theatre in downtown Oslo. Police soon arrived in great numbers to explain 
that the demonstration was illegal, and that the tents must be removed. Asmar explained to the chief police officer why they demonstrated:

I'm saying, you know how many people are getting paperless. They have the only choice to go to the street and when they go to the street, you know, like underground society, which have everything wrong. And we choose not to. That's why we are here, that's why we try. And I think in my opinion we are doing Norway a favour. You don't want us? OK. Find a solution. But don't leave us in the street. We are here representing 700 Palestinians. Many of them - they live now for two, four or more years without paper. They have to do black work, they have to ... I don't know. These 700 people, they don't want this, they don't want to be paperless, they don't want to be an underground society. They want to be in the open, but the government is forcing us to be paperless.... So help us. Find a solution, that's what we are trying to do. And I think this is in favour of us and in favour of Norway. Otherwise we ... I don't know what other choices we have.

Asmar's appeal was to no avail, but he succeeded in juxtaposing the temporality of waiting with the legality of legitimate work by pointing out that the uncertainty facing migrants in a judicial limbo makes it impossible for them to adjust to the time-space of mainstream Norwegian society. This is why they are out of sync, out of kilter, in the wrong place, living the wrong temporality. Through migration law and control mechanisms, the authorities regulate the lives of these migrants and enable a situation of temporariness and unpredictability. Referring to their restricted opportunity space for making choices, Asmar intimates that the decisions by the authorities shape and restrict the migrants' possible futures (see also Sigona and Hughes 2012; Andersson 2014; Griffiths 2014; Khosravi 2014). An explicit goal for the authorities is to evict rejected asylum seekers as swiftly as possible (Bendixsen and Lidén 2017). The emphasis on fast eviction as a measure of strong governance is meant to strengthen popular trust in the asylum system by showing efficacy and vigour in their border control. Seen from the perspective of the irregulars, this measure is rightly understood as expressing a lack of trust from the authorities and creates a heightened sense of precarity. ${ }^{4}$ Long after the demolition of the Palestinian camp, at the height of the Syrian refugee crisis in spring 2016, UDI ran a poster campaign tempting irregulars to opt for assisted return with promises of a 10,000 NOK $(€ 1100)$ cash reward for the first 500 to take the bait.

Having been evicted from the city centre of Oslo, the Palestinians moved and expanded their camp. The new location, next to St James Church, was proposed by the Blitz activists. They correctly believed that the church management 
would allow the Palestinians to stay. St James Church is the city's only 'cultural church', and performs no regular church services. Its management is known for a progressive approach to diversity and multiculturalism, and hosts a broad range of cultural activities involving different segments of Oslo's diverse population. Upon arrival, the activists approached the verger of the church, informing him of their presence. The latter then phoned the police to explain, laconically, that the church was aware of the situation, and that there was no need for police to come, since the church owned the land.

And so they moved in, a score and then some of young or youngish Palestinian men; although a few women had taken part in the demonstrations, they never moved into the camp, since, as a rule, young Palestinian women are actively discouraged from living in the immediate vicinity of unmarried, unrelated young men.

At this early stage, the waiting was intimately tied to an expectation of a pending change in their legal status. The assumption was that when the Norwegian public, including the media, realized how the authorities had treated the irregular Palestinians, they would put pressure on the government to change its policy. We asked Basher (22), who had lived in Norway for two years, why he chose to participate in the protracted demonstration:

Because we have been waiting for long time to get positive answer or even a negative. It's just that period. I can't just stay one year waiting for an answer. And I think that we have the right to have a positive or to stay legally in Norway because of the Oslo agreement. You know about it. And I don't know why they act with us like this.

A Norwegian activist, standing next to us, asks: 'Was there any dialogue?'

No, they didn't contact us or any refugees. We just wait for our answer. And even if you try to call to know what your situation is, they will say 'don't call me again, if I need something, I will call you'. So we just have to wait ... one year, two years, three, no difference. And we know that time is money. Time is no difference here.

Synnøve asked, 'And what were you hoping to gain with the demonstration?'

What I hope to gain with the demonstration? A normal life after the demonstration. That they [Norwegians] know much more about us, about our situation. And we were hoping that they have some mercy, but I don't see this. So we will continue our demonstration until we know what we will do. Either we stay illegally, or you can just send us back. And they can't. ... You can't send me back, and you don't want me to live here. 
The activist asks: 'So what is the status, then, of the people who have the final rejection, and who cannot be sent back?'

Just sitting in the mottak [asylum centre] waiting for nothing. Because their cases are closed. They're just sitting there. They talk about democracy and human rights, but there are no human rights.

Rather than remaining in the asylum centres awaiting the next move from the authorities, the migrants decided to become visible in the public sphere, hoping for a 'normalized' future. Basher, here talking on behalf of the Palestinian migrants, emphasizes their mobilization as a contrast to the more passive waiting typical of other asylum seekers; while the latter are 'waiting for nothing' and are 'just sitting there', the Palestinians decided to shift to a linear, goaldirected temporal regime enabling them to contribute to change. By setting up the camp, they established an active relationship to their own lives and notions of the future, thereby turning the passive time of waiting into a time of projectoriented activity. The tented camp could thus be seen as a materialization of the way in which futurity is expressed, with an established life in Norway as the ultimate goal. It expresses hope, and what you hope for is that which you cannot be certain of; it is a future at once utopian and possible. Hope is the energy enabling people stuck in quicksand to hoist themselves up by the bootstraps.

\section{Hope and liquid time}

The ability to hope, says Hage (2003), enables people to invest and act upon a social reality, even when the chance of achieving your goals is slim and fear is a constant companion. Bourdieu, likewise, has argued that hope can be understood as an emotion enabling agency for 'people without a future' (Bourdieu 2000: 221). Ernst Bloch, in his monumental study of hope, Das Prinzip Hoffnung (1986 [1954]), regards hope as a basic quality of what it means to be human. Comparing Christian and Marxist expressions of hope, Bloch argues, against orthodox Freudianism, in favour of bringing to the surface the 'not yet conscious'. His view, which seemed credible to many in the midtwentieth century, was that Marxism represented the fullest, most consistent and realistic vision of hope. Inspired by Bloch, but updating him to engage fully with the fragmented, postmodern, neoliberal, globalized world of the early twentyfirst century, Appadurai (2013) sees utopian hope now not in the grand visions of a historical teleology such as Marxism, but in the small-scale mobilizations 
of social movements, largely in the Global South, and their transnational ties. The hope expressed in the tented camp is consistent with Appadurai's analysis: the residents of the camp have no ambition to change the world, or the course of history, but by speaking truth to power, they believe in the betterment of their own lives through contributing to a juster and more equitable politics from the Norwegian state. By doing so, we may well argue with Benjamin and other utopian socialists, they nevertheless fight for a kind of justice that may, if turned into a principle, contribute to greater fairness in general.

During the early demonstration at Eidsvolds Plass, journalists and curious passers-by approached. While Bendixsen was standing there, a student asked Basher what it was like to live in an asylum centre. Basher eventually explained the implications of having your application rejected:

And the other choice they [migrants] maybe have in their minds is [to be transferred to a] deportation camp, which is worse, and this is like our biggest fear. Because deportation camp is worse than mottak [asylum centre], because it's just deportation. ${ }^{5}$... But the idea is not about the place itself, it's not about having food and nice things and TV or luxury. It's not about this, it's about the situation: 'Till when I have to stay in this camp? Till which date?' And as a Palestinian who cannot be deported by force - in most cases cannot be deported at all? You have to stay ... you don't have a deadline, you know, so you can stay for years and years. That's our biggest fear, that they send us to the deportation centres, that we will stay for a long, long time. There is no end to this, and they know it, they know it very well. And this is what makes it more frustrating for us.

An important implication of waiting is the control by others over one's own life. Certain places where asylum seekers were being detained were described as places where the waiting had no deadline. Waiting for a long time is to be the subject of an assertion that one's own time (and therefore, one's social worth) is less valuable than the time and worth of the one who imposes the wait' (Schwartz 1975: 856). As shown in the perhaps most significant literary work about waiting, power and uncertainty, namely Kafka's The Process, the punitive aspect of waiting consists of ensuring that the person who waits is kept in the dark regarding both the length and the outcome of the wait.

In Basher's view, the authorities do not understand the psychologically denigrating effects of indeterminate waiting - what we call liquid time - in asylum centres, by exclusively focusing on material conditions. The uncertainty about the length and outcome of the waiting instilled fear in Basher, which was directly related to a possible, undesired future, namely deportation following a long period of waiting, that would then appear as futile and 
meaningless. To some, this fear may be debilitating and paralysing (Boehm 2009), while in Basher and other Palestinian migrants, it inspired agency in an attempt to replace waiting characterized by inertia with waiting that was filled with hope. ${ }^{6}$

Although life in the tented camp could be uneventful and boring, its temporality had a different quality to that of the asylum centre. There were days when the residents whiled the time away playing cards, drinking tea, loitering on the church steps or drifting aimlessly in the streets, representing a temporal regime seen as meaningless not only from the perspective of greater society, but also from the refugees' point of view since these non-directional activities showed that life was at a standstill. The political engagement, too, was not always at the forefront, and events at home (in Palestine) were gossiped about, family ties were maintained, and the young men might mourn a death of a relative or the end of a love relationship. Yet the tedium of the camp was, unlike that of the asylum centre, a result of a combination of undirected time where work or education was not possible, and an unrealized wish that future plans should materialize. Their visibility in Norwegian society and proximity to the everyday lives of others, who passed by just a few metres away, held out the possibility that something wonderful might happen at any moment, and that their lives were part of a larger narrative about politics, humanity and justice. In this, the migrants' determination to shift from a liquid temporality of monotonous repetition to one of hope was consistent not only with Appadurai's analysis of grassroots mobilization, but as will be shown, also with Bloch's loftier utopian thought.

This also shows an important cultural dimension to the waiting taking place in the camp, and the lives of the Palestinians in the tented camp express a stark clash of temporalities. Protestant Norway is a society where the vast majority of the adult population engages in wagework, regardless of gender, and where wagework and morality are deeply connected (Rugkåsa 2012). The first question a Norwegian asks when s/he meets a new person at a festive occasion is, 'So, and what do you do?' Oil-rich Norway is an accelerated society whose citizens walk faster, talk faster and consume more efficiently than their parents or grandparents did (Eriksen 2015; cf. Rosa 2015). The potentially harmful effects of instantaneous, ubiquitous mobile communication technology are recurrent topics of discussion from the lunch room to the media. In this society, courses in 'mindfulness' and the like have become popular in recent years (Madsen 2013), as a way of voluntarily enforcing slowness and self-awareness in a cultural world where slow time has become a scarce resource. Yet, we should recall, the slow 
time associated with la durée has value and a cumulative, liberating potential only when it is chosen, which in the case of irregular migrants it is not. The contrast between the inactivity of waiting imposed on the temporary residents of the camp and the surrounding goal-directed, fast and efficient mainstream society was stark, arguably starker than it would have been had the camp been established in a Middle Eastern country instead.

\section{The present as a fragile hinge between past and future}

The transition from indeterminate, empty waiting time to focused, activitydriven waiting time presupposed a range of activities, such as organizing a music festival, inviting politicians to the camp and interviews with the media. We have described the demonstrations, the contact with Norwegian NGOs and free-ranging activists (such as the 'Blitzers'), and the help received from Palestinians with resident rights; and we have also mentioned that visitors were welcomed and often encouraged to drop by the camp. A major event in the effort to shift from passive to active waiting, as in 'stalking a prey' (that is, the coveted documents from the government), was a musical festival organized just after the summer of 2011. Not exactly a summer of love, 2011 was the year in which Norway suffered a shocking massacre at the hands of a right-wing terrorist; and the autumn signalled, as it happened only fleetingly, a need for a more inclusive, cosmopolitan attitude towards minorities and diversity.

The rationale behind the event was partly to raise money for subsistence, but also to attract the attention of the media and the Norwegian population. Familiar Norwegian musicians played for free at the festival, where documentaries from Palestine (Promises, Checkpoint) were also broadcast in one of the party tents where a handful of migrants usually slept. There was also a small photo exhibition featuring historical photos from the early twentieth century, from the time of the 1948 Nakba ('the catastrophe') of eviction and subsequent Israeli occupation, of Palestinian refugee camps and on to the Palestinian camp in Oslo, entitled for the occasion 'the first Palestine refugee camp in Europe and outside the Middle East'. The photos were arranged chronologically, giving the present predicament historical depth and context.

The entrance ticket was a laminated copy of a Palestinian passport. A Land Rover was made to appear as an Israeli military vehicle, parked at the entrance and equipped with a sign saying 'Stop! Checkpoint!'. Two of the migrants 
played the part of Israeli soldiers, checking the entrance tickets (or 'passes') and performed body searches similar to the routine at Israeli checkpoints. There were T-shirts, postcards and other merchandise for sale, and before the music began, a debate was organized with participation by Norwegian politicians and Palestinian refugees.

The narrative about the sufferings of the Palestinian people was a major, recurrent theme throughout the festival. By connecting the refugee situation in the West Bank with the present camp in Oslo, the organizers appealed to the historically strong Norwegian engagement, particularly on the left side of the political spectrum, with Palestine. One of the effects of this time-space compression (Harvey 1990) linking Palestine in 1948 with Norway in 2011 was to raise critical questions about Norway's policy towards foreigners, whether outside the country (foreign policy) or within it (immigration policy). Norway's consistent and continued support of Israel was not mentioned explicitly, but tacitly acknowledged in this juxtaposition. The chronology of camps, beginning in the Middle East in the mid-twentieth century, ending in Northern Europe in the early twenty-first, also expressed a possible future where the provisional camp in Oslo represented the beginning of a mushrooming of Palestinian camps on European territory.

The emphasis on suffering and refugee camps expresses a collective selfunderstanding centred on victimhood. While the activities around the tented camp sought to establish a temporality of hope and future autonomy, one possible interpretation of the exhibition at the festival is, accordingly, that although the struggle continues on a small scale (in Oslo) and a large scale (in Palestine/ Israel), so will waiting and suffering. For a long time, a large, old, rusty key hung on the wall of a 'Palestinian embassy' in the camp. Residents pointed out that 'all' Palestinians had such a key, and it is indeed common to see people on the West Bank with a key in a chain around their neck, like an item of jewellery. The key signifies loss and nostalgia for the homes, both physical and metaphorical ones, that were lost after the Nakba. Some even carry the original keys to the homes they had to abandon in 1948, explaining that they, or their parents or grandparents, had locked their houses then, hoping one day to return and open the door. To Palestinians, the key has become a symbol of their ongoing exile, expressing the right to return and defiance in the face of continued occupation. As pointed out by George Bisharat (1997), the relationship to place among contemporary Palestinians in exile is 'more self-conscious [than before] ... and an attempt to reconcretize a connection to the land that had been violently sundered' (Bisharat 1997: 217). 
The key can be regarded as - metaphorically this time - a key symbol (Ortner 1973) transcending the boundaries of time and space, and signifying not only exile in Palestine, but exile in Norway and the right to a home, whether it is located in Jaffa or Trondheim. The photo exhibition, the key, the staging of border controls, the fake passes and the Land Rover were meant to give the Palestinians legitimacy as authentic asylum seekers, as members of a people condemned to perennial exile, almost like the Jews after the sacking of the Second Temple. Their parents' and grandparents' status as refugees has virtually been inherited. On a Facebook page devoted to the tented camp, a young man wrote the following poem:

\author{
MOHAMMED: Without Bathroom \\ Without water \\ Without electricity \\ Without a wall or roof \\ Without floor \\ Live like our grandparents in 48 \\ But this time in Norway
}

These very explicit references confirm and strengthen a mythical temporality whereby the connection between the past, the present and the future is being reproduced in a particular configuration of time-space compression. The Palestinians, moreover, draw on this continuous narrative of displacement and exile in order to justify their protests against rejections of asylum applications. The temporality expressed, with a seamless continuity between past and present, suggests that since they have been badly treated by Israel, the Norwegian Government is in effect an accomplice of Israel if it refuses them asylum. At the same time, the photographs, the key, the poems, the slogans and the tented camp itself can be understood as strategic tools materializing and producing concepts of the future in the present. Identity is never 'nothing but' strategic or meaningful; it is always both.

Another conceptualization of the future that was projected in the camp was that of a free Palestine. The demonstration slogans they used in Oslo switched between two temporalities; between a large-scale, long-term vision for an independent Palestine, depicting the Palestinians as a nation-in-waiting, and the small-scale, short-term demands on behalf of migrants waiting for legal documents enabling them to stay in Norway. However, against the Blitzers' occasional emphasis on the struggle for a free Palestine, the local Palestinian sans-papiers responded that 'We are here, not in Palestine!' To them, a free 
Palestine was envisioned as a utopian goal, much further ahead and more difficult to achieve than refugee status in Norway. It was precisely because a free Palestine seemed so utopian and unrealistic for the time being that they demanded recognition as bona fide refugees in Norway.

\section{Waiting as a tear in the temporal fabric}

While the myths of origin in the tented camps generated an idea of a continuous liminality from 1948 until today, depicting the Palestinians as a 'people in waiting, their everyday life and ongoing relationship with family members in Palestine created a different kind of liminality, on a smaller scale. Liminality, a temporal concept cunningly merging individual transformation and social continuity in its initial usage, was originally used to make sense of rites of passage (van Gennep 1909; see also Turner 1967). The term refers to the undefined period connecting two clearly defined statuses or social positions. The trials and tribulations to which young people are subjected at initiation in a vast range of societies, whereby they are stripped of previous identities and subsequently reincorporated as a new kind of person, may be likened to the state of liminality experienced by migrant asylum seekers who find themselves in a limbo, a liminal phase between their settledness in the country of origin and their legal inclusion into the country of destination (Khosravi 2010), the main difference being that the latter form of liminality has no predefined outcome.

The indefiniteness of liminality also indicates why the present is not experienced as meaningful, at the same time as it is indeterminate and potentially eternal. When hope cannot be fixed to a definite future moment (e.g. your marriage, your initiation, your final exam etc.), the present liminal state seems to continue forever without turning into a future. Life is on hold. Liminality eats itself backwards and forwards in the subjectively experienced time of la durée, and the present becomes ever more pressing as time passing. The present intensifies, like waiting at a bus stop for a bus that never arrives.

Such an experience of liminality was made apparent in many of the conversations we had with migrants. We asked Ahmed if he is in contact with friends outside of Norway:

My chat is always offline because all my friends [outside Norway] are doing very good, but I'm nothing. My life stopped since two years, my life is nothing. What should I write to them? 
Ahmed explains that he also has reduced his frequency of contact with his family, although he phones his mother regularly.

If not, then she worries. Every three week I call her - every one month. Not more than that, because I don't have any news. The first question was always 'have you got positive?' Now it is always: 'have you found wife? Have you married?' I'm the eldest, but all the others are married, all have children. She thinks too much about this. In Palestine you are 25 years max then married. Not 34 years! [His age.] In Palestine the family is the first - every Friday they eat, visit, go swimming. My mother tells me 'If you marry, I wouldn't think so much. She will cook, clean, have children.' But I'm not married. When I hear that, I don't call her - I want to give her good news.

Here, Ahmed identifies a crucial aspect of an irregular life situation, shared also by migrants from Iran, Iraq, Afghanistan and Ethiopia/Eritrea in Bendixsen's ethnography on irregularity with both women and men, namely the lack of opportunity to start a family and thereby leave the liminal phase behind permanently. The desire to start a family was most frequently mentioned in connection with the expectations from family in the home country, who expected them to do so. Many irregular migrants would be loath to elaborate on the full extent of their precarity to their hopeful family members at home, and are therefore often met with incredulity at the extent to which they are unable to send remittances or start a family life.

The significance of the liminal phase is gendered. To some of the women we spoke with, lengthy irregularity entails that they consider having children in spite of their unstable situation, since it will one day be too late to do so. To the male, unmarried migrants, the main pressure came from without, through pressure from relatives to leave their liminality, grow up and prove themselves to be men rather than boys. The state of liminality made cumulative projects involving development and growth impossible. Socially speaking, they are standing still, or they live in an eternally timeless, liquid present, and this is being confirmed whenever they meet people whose lives move ahead, such as the Norwegians involved with the camp.

Prolonged liminality, timeless time between fixed positions, is a threat to the cumulative, linear projects of economic independence and raising a family, and - in the case of women - to their ability to show themselves worthy by having children. It is therefore not without a certain interest that liminality is hailed as a superior mode of existence in mainstream neoliberal information society. The cult of youth witnessed in advertising and popular culture suggests that the 
ideal state of being is as a 19 year old. Being flexible and willing to change is widely considered a positive quality in the labour market, and jobs are often defined in terms of projects rather than stable content (Sennett 1998; Eriksen 2005). Stability, in this age of flux, movement, hybridization and change, is an indication of stasis and stagnation.

The difference between the two kinds of liminality is evident, but needs some further unpacking. (i) The irregular migrants are not net contributors to GDP. They are inefficient consumers and non-producers in the formal economy. The eternal youths of the information society, by contrast, remain highly efficient consumers throughout their lives, since fast and efficient consumption can compensate for the lack of a strong personal identity. (ii) Another important difference concerns the rhythm of a liminal existence. If that of the irregular migrants can be described as a life in slow motion, fully committed participants in the information economy lead lives that stand still at a hundred kilometres an hour (Eriksen 2001; see also Hassan and Purser 2007). (iii) Mainstream, card-carrying members of the information society, moreover, are marinated in individualism and the gospel of the freedom of choice, while the asylum seekers across from St James Church have strong family commitments and are embedded in a set of cultural values with certain scripts for the achievement of manhood and womanhood that may somewhat alter depending on your class, but in general where your obligations towards others weigh more heavily than your freedom. (iv) Finally, degrees of autonomy distinguishes the two categories in obvious, but no less important ways. Stressed citizens of the information society could choose slowness, and some do (Honoré 2004), while irregulars cannot choose either speed or engaging in projects entailing cumulative growth and development. They are trapped in a state of unwanted liminality, where time does not move anything forward except their irrepressible biological aging.

The tented camp was eventually demolished, after months of political pressure, in autumn 2012. By now, it had become abundantly clear that hopes for permits of residence were seriously weakened, if not evaporated. Some of the residents moved on to Sweden, a more liberal country than Norway in matters of immigration; some moved in with friends and got by economically in the informal sector; and one individual eventually got his legal permit of residence. Several of the central figures in the Palestinian group expressed disappointment, stating that they had wasted a lot of time trying to appeal to the Norwegian authorities. One of them, Ali, expressed a widely shared sentiment: 
Something good came out about it [the tent camp]. But I did not make anything for two years! If I had not been here in Oslo, I would be in a different country. When I came here, I didn't know how quickly time goes - all the time new meetings with the government, parliament. We think the problems will finish soon, because we have access to these people - that people from the government talked to us [made them believe that their problems would be solved soon]. We dream, think, but then finish with nothing. It's very bad. We have very bad health, back problems, before not a problem, but now I feel that I'm 50 years old.

The fact that local and even national politicians came to the camp and heard the refugees out was both surprising and a source of hope for the young men, whose experience from their home country suggested that the distance between common people and politicians was usually far greater. Yet, in the end, nothing came out of these meetings, and the erstwhile residents of the camp might feel older, perhaps somewhat wiser, but not satisfied that they had contributed to a worthwhile cause. By stating that they had wasted their time by pursuing political mobilization that was partly an appeal to the Norwegian authorities, they also criticize state policies, procedures and practices that structured their lives (cf. Rotter 2016). Rejected migrants who accepted voluntary return with the International Organization for Migrants (IOM) often commented that they wished that they 'hadn't spent so much time' before returning (Øien and Bendixsen 2012). Others, who chose to stay in Europe in the hope that some country would accept their wish to start their life in earnest, argued that if they were to return now, the years as irregulars would feel like 'wasted time'. In this way, waiting does not just entail several stages, from the short to the long term. The period of waiting can also attain a new meaning retrospectively when the future, in this case the securing of legal residence permits, did not materialize after all, and became instead one of those possible futures that never happened. Changes in the opportunity structure, defined from outside rather than within, may close doors that were previously open, or close doors that long seemed to be ajar.

\section{The hard work of recapturing time}

We have shown how hope and indeterminacy alternate in liminal time when an asylum application has been rejected and the applicant appeals the decision. Hope entails that time is directed, linear and cumulative; indeterminacy suggests entrapment in a state of eternal limbo or liminality. The Palestinian mobilization can be seen as an endeavour aiming to reshape empty waiting 
time to the directed, meaningful temporality of hope, and as an attempt to regain the power to shape one's own temporality. Conceptualizations of the future - whether undesired (enforced return), desired (permit of residence), utopian (free Palestine) or expected (start a family) - were sources of fear and hope, prompting action in the present in the expectation that they might shape the future. The mobilization and the establishment of the camp were attempts to recapture time, to help decide when waiting would end and the future would begin.

Waiting in hope and anticipation connects the past and future through the conviction that 'my waiting will result with the fulfilment of my wishes' (BozicVrbancic 2009: 191), but the transformation from passive to active waiting that we have explored in this chapter is essential since it inserts agency into the sometimes exasperatingly sluggish flow of time entailed by waiting. In order to combat the seemingly eternal liminality experienced by refugees waiting for papers that never seem to come, people depend on hope, frequently mixed with fear, in order to act.

The axis liminal/passive versus goal-oriented/active must be understood within a broader typology of different forms of waiting. By filling waiting time with social time, waiting may seem productive and momentarily meaningful, but it may yet be perceived as useless and wasteful retrospectively if the objective of the waiting is never reached - the dentist never appears in the waiting room, the beloved fails to return your calls, the stone-faced ministry never sends you the official letter you need for your life as a card-carrying human being to begin. Filling the emptiness of waiting with political mobilization aimed to create a future as a person with a proven identity concerns the ways in which people structure their experience of lasting uncertainty, while simultaneously confirming the liminality and precarity of the migrants. Although this time is invested with meaning and cumulative projects towards a defined future, uncertainty continues to enter as a counterpoint, as a kind of antimatter, thereby continuing to confirm the temporariness and liminality of the migrants. They nevertheless succeed in limiting the power of others to make them wait by filling the empty time imposed by the authorities with content. Theirs are acts of defiance. Turning Foucault (1978) on his head, Abu-Lughod (1990) says that where there is resistance, there is power. We have shown that the acts of resistance invested in and around the tented camp next to St James Church of Culture did not merely, or even chiefly, concern the instrumental objective of obtaining political asylum. It was also, or perhaps chiefly, a rebellion against the wilful emptying of their time on the part of the authorities, an insistence to be 
allowed agency even in a state of limbo where one's existence as a person was in doubt. A matter for further inquiry concerns the ways in which waiting time is an expression of someone's power over somebody else. The production of wasted time, or waiting time, among migrants is one of the ways in which the state expresses its power. By rebelling against this imposed passivity and clientification, whether effectively or not, the refugees not only give anthropologists of time grist for their mill, or seek to improve their personal lives. They also challenge a political order where temporal autonomy is unequally distributed.

\section{Acknowledgements}

The authors would like to thank Manpreet K. Janeja and Andreas Bandak for exceptionally detailed and relevant comments on the first draft.

\section{Notes}

1 UDI, Utlendingsdirektoratet, is the Norwegian Directorate for Immigration.

2 UNE, Utlendingsnemda, 'the Foreigners' Tribunal', handles appeals against rejected applications for immigration to Norway.

3 There is some empirical overlap between this chapter and an article in Norwegian (Bendixsen 2015b).

4 Whyte (2011) describes how the asylum system in Denmark works as a technology of power. Asylum seekers' waiting time was structured by uncertainty, which, he argues, was part of the operation of the system.

5 The uncertainty, fear and indeterminacy of life in a deportation centre is described by Marie Amelie in her second book (Amelie 2014), which is based on her personal experiences at Trandum deportation centre after having been arrested following the publication of, and widespread acclaim for, her first book about being 'illegally Norwegian' (Amelie 2010).

6 Research indicates that irregular migrants apply for assisted return (AR) when they have lost all hope that they will achieve a residence permit in the country where they have applied for asylum (Bendixsen and Lidén 2017). The decision to stop waiting and instead return, however, is not only tied to the period of time spent waiting, but also to experiences of not being able to meet family obligations, personal or structural changes in the situation in the country of return (such as family death or security improved), or being unable to meet social expectations, such as marriage and work (Bendixsen and Lidén 2017). 


\section{References}

Abu-Lughod, Lila. 1990. 'The Romance of Resistance: Tracing Transformations of Power Through Bedouin Women'. American Ethnologist 17(1): 41-55.

Agamben, Giorgio. 1998. Homo Sacer: Sovereign Power and Bare Life. Stanford, CA: Stanford University Press.

Amelie, Maria. 2010. Ulovlig norsk (Illegally Norwegian). Oslo: Pax.

Amelie, Maria. 2014. Takk (Thank you). Oslo: Pax.

Anderson, Benedict. 1983 . Imagined Communties: Reflections on the Origin and Spread of Nationalism. London: Verso.

Andersson, Ruben. 2014. 'Time and the Migrant Other: European Border Controls and the Temporal Economics of Illegality'. American Anthropologist 116(4): 795-809.

Appadurai, Arjun. 2013. The Future as a Cultural Fact: Essays on the Global Condition. London: Verso.

Auyero, Javier. 2012. Patients of the State: The Politics of Waiting in Argentina. Durham, NC: Duke University Press.

Bauman, Zygmunt. 2004. Wasted Lives. Modernity and its Outcasts. Cambridge: Polity.

Bayart, Jean-François. 2007. Global Subjects: A Political Critique of Globalization. Cambridge: Polity.

Bendixsen, Synnøve. 2015a. 'Vilkårlige rettigheter? Irregulære migranters tillit, sosiale kapital og kreative taktikker' ('Arbitrary rights? The trust, social capital and creative tactics of irregular migrants'). In Eksepsjonell velferd? Irreguloere migranter i det norske velferdssamfunnet (Exceptional welfare? Irregular migrants in the Norwegian welfare society), edited by Synnøve K. Bendixsen, Christine M. Jacobsen and Karl Harald Søvig, 184-202. Oslo: Gyldendal.

Bendixsen, Synnøve. 2015b. “'Give me the damn papers!” Å vente på oppholdstillatelse. ('Give Me the Damn Papers!' Waiting for a Permit of Residence). Norsk antropologisk tidsskrift 26(3-4): 285-303.

Bendixsen, Synnøve. 2017. 'Voice Matters: Calling for Victimhood, Shared Humanity and Citizenry of Irregular Migrants in Norway'. In Within and Beyond Citizenship. Borders, Membership and Belonging, edited by Roberto G. Gonzales and Nando Sigona, 185-207. London: Routledge.

Bendixsen, Synnøve and Hilde Lidén. 2017. 'Return to Well-being? Irregular Migrants and Assisted Return in Norway'. In Return Migration and Psychosocial Wellbeing, edited by King Russel and Zanna Vathi, 21-38. London: Routledge.

Benjamin, Walter. 1968 [1939]. 'On Some Motifs in Baudelaire'. In Illuminations, edited by W. Benjamin, 155-200. New York: Schocken.

Bergson, Henri. 1935. Two Sources of Morality and Religion. London: Macmillan. Bergson, Henri. 2001 [1889]. Sur les données immédiates de la conscience. Paris: PUF. Bisharat, George. 1997. 'Exile to Compatriot: Transformations in the Social Identity of Palestinian Refugees in the West Bank'. In Culture, Power, Place: Explorations 
in Critical Anthropology, edited by Akhil Gupta and James Ferguson, 203-233.

Durham, NC: Duke University Press.

Bloch, Ernst. 1986 [1954]. The Principle of Hope. Cambridge, MA: MIT Press.

Boehm, Deborah A. 2009. “'Quien sabe?”: Deportation and Temporality among

Transnational Mexicans.' Urban Anthropology and Studies of Cultural Systems and World Economic Development 38(2-4): 345-374.

Bourdieu, Pierre. 1977. Outline of a Theory of Practice. Cambridge: Cambridge

University Press.

Bourdieu, Pierre. 2000. Pascalian Meditations. Cambridge: Polity.

Bozic-Vrbancic, Senka. 2009. 'Waiting to Be Loved: The European Union's Hope to Be

the Loved Object'. In Waiting, edited by Ghassan Hage, 184-194. Carlton South:

Melbourne University Press.

Brekke, Jan-Paul. 2004. While We Are Waiting: Uncertainty and Empowerment Among Asylum-Seekers in Sweden. Report 2004: 10. Oslo: Institute for Social Research.

Brekke, Jan-Paul. 2010. 'Life on Hold: The Impact of Time on Young Asylum Seekers Waiting for a Decision'. Diskurs Kindheits- und Jugendforschung 5(2): 159-167.

Brun, Catherine. 2015. 'Active Waiting and Changing Hopes: Toward a Time

Perspective on Protracted Displacement'. Social Analysis 59(1): 19-37.

Chimienti, Milena and John Solomos. 2011. 'Social Movements of Irregular Migrants, Recognition, and Citizenship'. Globalizations 8(3): 343-360.

Corcoran, Paul E. 1989. 'Godot is Waiting Too: Endings in Thought and History'. Theory and Society 18: 495-529.

Crapanzano, Vincent. 1985. Waiting: The Whites of South Africa. New York: Random House.

de Genova, Nicholas. 2010. 'The Deportation Regime: Sovereignty, Space, and the Freedom of Movement'. In The Deportation Regime: Sovereignty, Space and Freedom of Movement, edited by Nicholas de Genova and Nathalie Peutz. Durham, NC: Duke University Press.

de Genova, Nicholas and Nathalie Peutz (eds.). 2010. The Deportation Regime: Sovereignty, Space, and the Freedom of Movement Durham, NC: Duke University Press.

Eriksen, Thomas Hylland. 2001. Tyranny of the Moment: Fast and Slow Time in the Information Age. London: Pluto.

Eriksen, Thomas Hylland. 2005. 'Mind the gap: Flexibility, Epistemology and the Rhetoric of New Work'. Cybernetics and Human Knowing 12(1-2): 50-60.

Eriksen, Thomas Hylland. 2015. 'Afterword: Beyond the Paradox of the Big, Bad Wolf'. In Sustainable Consumption and the Good Life, edited by Karen Lykke Syse and Martin Lee Mueller, 260-275. London: Routledge.

Foucault, Michel. 1978. The History of Sexuality. Vol. 1: An Introduction. New York: Random House.

Gasparini, Giovanni. 1995. 'On Waiting'. Time \& Society 4(1): 29-45. 
Gray, Brenda. 2011. 'Becoming Non-migrant: Lives Worth Waiting For'. Gender, Place \& Culture 18(3): 417-432.

Griffiths, Melanie. 2014. 'Out of Time: The Temporal Uncertainties of Refused Asylum Seekers and Immigration Detainees'. Journal of Ethnic and Migration Studies 40(12): 1991-2009.

Griffiths, Melanie, Ali Rogers and Bridget Anderson. 2013. 'Migration, Time and Temporalities: Review and Prospect'. COMPAS Research Resources Paper. Oxford: Centre on Migration, Policy, and Society (COMPAS), University of Oxford.

Hage, Ghassan. 2003. Against Paranoid Nationalism: Searching for Hope in a Shrinking Society. London: Pluto.

Hage, Ghassan. 2009. 'Introduction'. In Waiting, edited by Ghassan Hage, 1-14. Carlton South: Melbourne University Press.

Harvey, David. 1990. The Condition of Postmodernity: An Enquiry into the Origins of Cultural Change. Cambridge: Blackwell.

Hassan, Robert and Ronald E. Purser (eds.). 2007. 24/7: Time and Temporality in the Network Society. Stanford, CA: Stanford Business Books.

Hodges, Matt. 2008. 'Rethinking Time's Arrow: Bergson, Deleuze and the Anthropology of Time'. Anthropological Theory 8(4): 399-429.

Honoré, Carl. 2004. In Praise of Slowness. London: Orion.

Khosravi, Shahram. 2010. 'Illegal' Traveller: An Auto-Ethnography of Borders. London: Palgrave Macmillan.

Khosravi, Shahram. 2014. 'Waiting: Keeping Time'. In Migration: A COMPAS Anthology, edited by Bridget Anderson and Michael Keith, 66-67. Oxford: COMPAS. http:// compasanthology.co.uk/waiting/. (accessed 20 February 2015).

Kjærre, Halvar A. 2010. 'No Direction Home - The Margins of a Welfare State and the Illegalized Body'. In Irregular Migrations in a Scandinavian Perspective, edited by Trine Lund Thomsen, Martin Bak Jørgensen, Susi Meret, Kirsten Hviid and Helle Stenum, 231-257. Maastricht: Shaker Publishing.

Lakha, Salim. 2009. 'Waiting to Return Home: Modes of Immigrant Waiting. In Waiting, edited by Ghassan Hage, 121-134. Carlton South: Melbourne University Press.

Madsen, Ole Jacob. 2013. 'Det er innover vi må gå’: En kulturpsykologisk studie av selvhjelp ('We must go inwards': A cultural psychological study of self-help). Oslo: Universitetsforlaget.

Mohn, Sigmund B. et al. 2014. Et marginalt problem? Asylsøkere, ulovlig opphold og kriminalitet (A marginal problem? Asylum-seekers, illegal residence and crime). Kristiansand: Oxford Research. http://www.udi.no/globalassets/global/forskningfou_i/beskyttelse/et-marginalt-problem—endelig.pdf. (accessed 10 October 2014).

Mountz, Alison. 2011. 'Where Asylum-seekers Wait: Feminist Counter-topographies of Sites between States'. Gender, Place \& Culture: A Journal of Feminist Geography 18(3): 381-399. 
Øian, Hogne. 1998. 'Arbeidsfri og fritidsløs. Om unge arbeidsledige i Oslo og deres møte med det etterindustrielle lønnsarbeidsregimets krav om lineære karrierer' (Unemployed and unleisured: On young unemployed in Oslo and their encounter with the demands of linear careers in postindustrial society). $\mathrm{PhD}$ dissertation, Department of Social Anthropology, University of Oslo.

Øien, Cecilie and Synnøve Bendixsen. 2012. Det riktige valget: Motivasjon og beslutningsprosess når avviste asylsøkere velger frivillig retur (The correct decision: Motivation and decision-making processes when rejected asylum-seekers choose voluntary return). Oslo: FAFO, FAFO-rapport 2012, 37.

Ortner, Sherry. 1973. 'On Key Symbols'. American Anthropologist 75(5): 1338-1346.

Pamuk, Orhan. 2012. Silent House. London: Faber and Faber.

Piaget, Jean. 1981. La Développement de la notion du temps chez l'enfant. Paris: PUF.

Rosa, Hartmut. 2015. Social Acceleration: A New Theory of Modernity. New York: Columbia University Press.

Rotter, Rebecca. 2016. 'Waiting in the Asylum Determination Process: Just an Empty Interlude?'. Time \& Society 25(1): 80-101.

Rugkåsa, Marianne. 2012. Likhetens dilemma. Om sivilisering og integrasjon i den velferdsambisiøse norske stat (The predicament of equality: On civilizing and integration in the welfare-ambitious Norwegian state). Oslo: Gyldendal Akademisk.

Rundell, John. 2009. 'Temporal Horizons of Modernity and Modalities of Waiting. In Waiting, edited by Ghassan Hage, 39-53.Victoria: Melbourne University Press.

Schütz, Alfred. 1967 [1932]. The Phenomenology of the Social World. Evanston, IL: Northwestern University Press.

Schwartz, Barry 1975. Queuing and Waiting: Studies in the Social Organization of Access and Delay. Chicago: University of Chicago Press.

Schweizer, Harold. 2004. 'On Waiting. University of Toronto Quarterly 74(3): 777-792.

Schweizer, Harold. 2008. On Waiting. London: Routledge.

Sennett, Richard. 1998. The Corrosion of Character. New York: Norton.

Sigona, Nando and Vanessa Hughes. 2012. No Way Out, No Way In: Irregular Migrant Children and Families in the UK. Oxford: COMPAS.

Thompson, E. P. 1967. 'Time, Work-discipline and Industrial Capitalism'. Past \& Present 38(1): 56-97.

Thomsen, Martin Bak Jørgensen, Susi Meret, Kirsten Hviid and Helle Stenum (eds.). 2010. Irregular Migrations in a Scandinavian Perspective. Maastricht: Shaker Publishing.

Turner, Victor W. 1967. 'Betwixt and between: The Liminal Period in Rites De Passage'.

In The Forest of Symbols. Aspects of Ndembu Ritual, edited by V. Turner, 93-111.

Ithaca, NY, and New York: Cornell University Press.

van Gennep, Arnold. 1909. Les Rites de passage. Paris: Emile Nourry.

Whyte, Zachary. 2011. 'Enter the Myopticon. Uncertain Surveillance in the Danish Asylum System'. Anthropology Today 27(3): 18-21. 